\title{
Microbial Regeneration of Nutrients from the Decomposition of Macrophyte Debris on the Shore
}

\author{
K. Koop ${ }^{1}$, R. C. Newell ${ }^{2}$ and M. I. Lucas ${ }^{2}$ \\ ${ }^{1}$ Zoology Department, University of Cape Town, Rondebosch 7700 , South Africa \\ ${ }^{2}$ Institute for Marine Environmental Research, Prospect Place, The Hoe, Plymouth PL1 3DH, England
}

\begin{abstract}
A mass balance for the decomposition of kelp in a sand beach microcosm shows that microbial incorporation of nitrogen from kelp debris is achieved within $7 \mathrm{~d}$ with an efficiency of as much as $94.2 \%$ of the particulate and dissolved carbon. Although comparatively high concentrations of carbon and ammonia appear in the leachates from kelp, these amount only to $0.2 \%$ of the carbon and $1.5 \%$ of the nitrogen originally present in the kelp debris. Estimates of the input of macrophyte debris to the shore from a kelp bed at Kommetjie, Cape Peninsula, South Africa, suggest that $206 \mathrm{~g} \mathrm{C} \mathrm{m}^{-1} \mathrm{~d}^{-1}$ are cast onto the strandline and that the organic nitrogen input is $12 \mathrm{~g} \mathrm{~m}^{-1} \mathrm{~d}^{-1}$. The carbon returned to the sea is thus $0.4 \mathrm{~g} \mathrm{~m}^{-1} \mathrm{~d}^{-1}$ while the nitrogen ist $0.2 \mathrm{~g} \mathrm{~m}^{-1} \mathrm{~d}^{-1}$ Although the ammonia released during decomposition of kelp debris on the strandline may have some strictly localised significance in the immediate subtidal zone, it is estimated that such leachates could meet only $0.09 \%$ of the nitrogen requirements of primary production in the nearby kelp bed, or approximately $0.4 \%$ of those of surf zone phytoplankton. Primary production in the adjacent subtidal communities is thus dependent mainly on in situ remineralisation of nutrients and on local upwelling, rather than on the regeneration of nutrients from material cast onto the strandline
\end{abstract}

\section{INTRODUCTION}

As is well known, a principal end product of microbial decompostion of nitrogenous debris in both terrestrial and aquatic environments is ammonia (for review see Fenchel and Blackburn, 1979). Under aerial conditions much of this may be lost to the atmosphere, but there is a good deal of evidence that the ammonia may be of importance in supporting primary production in aquatic environments. Lewin et al. (1975), for example, reported that ammonium was always present in surf at Copalis Beach, Washington, and that this probably represented a nitrogen source to sustain the dense populations of surf zone diatoms. Raine and Patching (1980) have shown that during the productive season the nitrogen supply to the water column, mainly in the form of ammonia from biological decomposition of imported organic matter in a semi-enclosed bay in Galway, Ireland, was in excess of local phytoplankton requirements. Again, McLachlan et al. (1981) estimated that the nitrogen in a sandy beach in Port Elizabeth, South Africa, was regenerated approximately every $8 \mathrm{~d}$ and suggested that the total nitrogen was of importance in sustaining primary production in the surf zone.
There have, however, been few attempts to determine the rate of supply of nitrogenous debris to the intertidal environment from areas of known primary production. There is also little information on the relative amounts of carbon and nitrogen from such material which is returned to the sea, or its quantitative significance in sustaining further primary production by the source of the organic material. The following study was therefore undertaken to follow quantitatively the decomposition products of kelp debris through a sand beach adjacent to a kelp bed of known primary production. Carbon flow through the system has been reported previously (Koop et al., 1982). The present paper summarises the flow of nutrients between cast up kelp and the adjacent nearshore environment.

\section{MATERLALS AND METHODS}

A sample of $26.35 \mathrm{~kg}$ wet weight of freshly-cut kelp (Ecklonia maxima Osbeck) was placed at high water of spring tides on a shore with sand patches at Kommetjie, Cape Peninsula, South Africa ( $\left.34^{\circ} 08^{\prime} \mathrm{S}: 18^{\circ} 18^{\prime} \mathrm{E}\right)$. Kelp was put in a cleft with a flat rock floor which 
Table 1. Summary of methods for analysis of nutrients in seawater samples. c.v. coefficient of variation. See also Armstrong et al. (1967) and Strickland and Parsons (1972)

\begin{tabular}{|c|c|c|c|}
\hline Nutrient & Method & Standard & Sensitivity (mg l $\mathrm{I}^{-1} \mathrm{c.v}$.) \\
\hline Ammonia & $\begin{array}{l}\text { Berthelot colour response with sodium } \\
\text { phenoxide and sodium hypochlorite }\end{array}$ & $\begin{array}{l}2 \mu \mathrm{mol} \mathrm{l}^{-1} \\
\text { ammonium sulphate in } \mathrm{N} \text {-free water }\end{array}$ & $0.2 ; 0.25 \%$ \\
\hline $\begin{array}{l}\text { Nitrite } \\
\text { Nitrate }\end{array}$ & $\begin{array}{l}\text { Copper-cadmium reduction of nitrite ion } \\
\text { and formation of azo dye }\end{array}$ & $\begin{array}{l}15 \mu_{\mathrm{mol}}{ }^{-1} \\
\text { potassium nitrate in } \mathrm{N} \text {-free water }\end{array}$ & $0.02 \mathrm{mgN} \mathrm{l}^{-1} ; 0.55 \%$ \\
\hline Phosphate & $\begin{array}{l}\text { Molybdophosphoric acid reduction to } \\
\text { molybdenum blue complex by ascorbic } \\
\text { acid }\end{array}$ & $\begin{array}{l}1.5 \mu \mathrm{mol} \mathrm{l}^{-\mathrm{t}} \\
\text { potassium dihydrogen phosphate in } \\
\text { ARISTAR (Merck) seawater }\end{array}$ & $0.2 ; 0.40 \%$ \\
\hline
\end{tabular}

drained into a small depression of approximately 101 volume (Pool 1). An overflow of excess fluids from this pool drained through a sand patch of $1 \mathrm{~m}$ length and $50 \mathrm{~cm}$ width with a depth of approximately $12 \mathrm{~cm}$ on an impervious rock floor. Finally, material from the sand could drain into a larger rock pool of 301 volume (Pool 2) (Koop et al., 1982). Fluids from Pool 1 were used to assay the chemical composition and microbiology of the initial kelp leachates. The sand strip allowed us to study the role of the interstitial microfauna in the degradation of dissolved and particulate matter entering the beach from the kelp while analyses of organic matter entering the larger Pool 2 represented material returned to the sea following processing activities by the sand (Fig. 1).

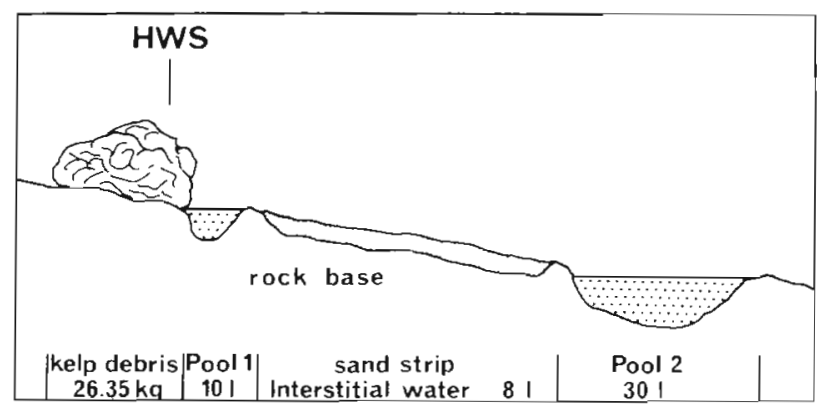

Fig. 1. Detail of study site at Kommetjie, Cape Peninsula, South Africa, showing the different components of the micro-

cosm studied. Average depth of the sand strip was $12 \mathrm{~cm}$

Desiccation of the kelp pile was prevented through the rapid formation of a superficial dry layer and at the end of the study all but this layer had disappeared through a combination of grazing by invertebrates and bacterial decomposition (Koop et al., 1982). The chemical composition of the dried out kelp appears to be remarkably stable - the $\mathrm{C}: \mathrm{N}$ ratio remained unchanged over the study period.

Samples of $40 \mathrm{ml}$ were taken daily from the initial leachates in Pool 1, from the interstitial water of the sand strip and from the final drainage Pool 2. The water was filtered through $25 \mathrm{~mm}$ Whatman GF/C filters and the filtrate frozen prior to analysis. Samples were analysed for ammonia, nitrite, nitrate and phosphate on a Technicon Auto Analyzer II. The analytical procedures are outlined in Table 1 , together with the standards used and the sensitivity of the method. The results are expressed in $\mu \mathrm{g}$-at $1^{-1}$ and for the purpose of the mass balance calculations were subsequently converted to total weights using the volumes of water in the components of the microcosm.

The total carbon and nitrogen of freeze dried material was analysed by combustion in a Heraeus CHN elemental analyser (Model EA415-50) using p-Nitroanaline $(52.17 \% \mathrm{C}$ and $20.28 \% \mathrm{~N})$ as a standard (see also Koop et al, 1982). All results were expressed as the mean for 3 weighed subsamples of approximately $3 \mathrm{mg}$ dry material.

\section{RESULTS}

\section{Carbon, Nitrogen and Phosphate in the Microcosm}

The concentrations of nitrogen and phosphate analysed in the initial leachate pool beneath the kelp (Pool 1), in the interstitial water of the sand column, and in the final drainage Pool 2 are summarised in Table 2. Carbon values recalculated from Koop et al. (1982) are also shown. It is clear that very high concentrations of $\mathrm{NH}_{3}$ accumulated over the experimental period after which time $92 \%$ of the kelp initially supplied to the microcosm had been decomposed. In contrast, nitrite, and to a greater extent nitrate, were low except in the interstitial water when grazing amphipods invaded the sand for a period of $3 \mathrm{~d}$. Phosphate showed an initial accumulation in the leachates but subsequently declined with time and with passage through the system, a maximum of only $16.21 \mu \mathrm{g}$-at $\mathrm{l}^{-1}$ appearing in the final drainage pool. Carbon values in the leachate pool were much higher than the nitrogen concentrations and showed a marked utilisation during passage through the microcosm. As noted by Koop et al. (1982), it is clear that almost all of the organic 
Table 2. Nutrient values ( $\mu \mathrm{g}$-at $\mathrm{l}^{-1}$ ) in leachates from the kelp Ecklonia maxima (Pool 1), in the interstitial water of a 1 m sand strip and in a subsequent drainage pool (Pool 2). The carbon values were recalculated from Koop et al. (1982). All data have been corrected for evaporation

\begin{tabular}{|c|c|c|c|c|c|c|}
\hline Day & C $10^{3}$ & $\mathrm{NH}_{3}$ & $\mathrm{NO}_{2}$ & $\mathrm{NO}_{3}$ & Total inorganic $\mathrm{N}$ & $\mathrm{PO}_{4}$ \\
\hline \multicolumn{7}{|c|}{ Pool 1} \\
\hline 0 & 6.05 & 32.56 & 0.73 & 0.05 & 33.34 & 0.42 \\
\hline 1 & 17.22 & 210.84 & 0.94 & 0.09 & 211.87 & 15.14 \\
\hline 2 & 52.78 & 1535.60 & 0.94 & 0.06 & 1536.60 & 115.12 \\
\hline 3 & 104.17 & 3443.00 & 0.98 & 0.06 & 3444.04 & 60.78 \\
\hline 4 & 128.06 & 5372.64 & 1.49 & 0.06 & 5374.19 & 468.69 \\
\hline 5 & 158.89 & 5809.34 & 2.63 & 0.12 & 5812.09 & 14.67 \\
\hline 6 & 107.22 & 6853.69 & 3.61 & 0.13 & 6857.43 & 17.26 \\
\hline 7 & 221.33 & 7280.60 & 4.71 & 0.16 & 7285.47 & 11.02 \\
\hline \multicolumn{7}{|c|}{ Interstitial } \\
\hline 0 & 13.33 & 198.00 & 0.73 & 0.11 & 198.84 & 0.85 \\
\hline 1 & 26.39 & 534.00 & 108.53 & 757.55 & 1400.08 & 1.50 \\
\hline 2 & 22.33 & 697.00 & 89.28 & 361.60 & 1147.88 & 2.35 \\
\hline 3 & 20.00 & 936.00 & 78.43 & 452.00 & 1466.43 & 1.34 \\
\hline 4 & 20.25 & 906.00 & 21.37 & 1.72 & 929.09 & 2.35 \\
\hline 5 & 25.25 & 1170.00 & 1.19 & 0.18 & 1171.37 & 8.57 \\
\hline 6 & 14.17 & 992.00 & 6.75 & 0.93 & 999.68 & 2.35 \\
\hline 7 & 13.89 & 1201.00 & 28.88 & 4.11 & 1233.99 & 1.79 \\
\hline \multicolumn{7}{|c|}{ Pool 2} \\
\hline 0 & 8.06 & 31.52 & 1.09 & 0.18 & 32.79 & 0.68 \\
\hline 1 & 6.39 & 255.65 & 13.43 & 1.11 & 270.19 & 3.02 \\
\hline 2 & 6.39 & 939.40 & 1.07 & 0.10 & 940.57 & 6.67 \\
\hline 3 & 11.39 & 1185.53 & 1.15 & 0.06 & 1186.74 & 9.46 \\
\hline 4 & 9.42 & 1395.26 & 1.97 & 0.11 & 1397.34 & 6.30 \\
\hline 5 & 8.58 & 1810.35 & 1.27 & 0.12 & 1811.74 & 12.76 \\
\hline 6 & 8.58 & 2023.04 & 3.75 & 0.13 & 2026.92 & 13.38 \\
\hline 7 & 10.56 & 2600.43 & 1.48 & 0.13 & 2602.04 & 16.21 \\
\hline
\end{tabular}

carbon is utilised in the microcosm by a combination of grazing and microbial activity.

In order to estimate the decomposition products accumulating in the microcosm, it is necessary to multiply the values shown in Table 2 by the volumes of initial leachate, interstitial water and water in the final drainage Pool 2. The values attained at the end of the experiment are shown in Table 3. These represent products which had not been utilised by microbial activity or consumers and which are thus available for

Table 3. Total amounts $\left(\mu \mathrm{g}\right.$-at $\left.\cdot 10^{3}\right)$ of material from decomposing kelp Ecklonia maxima accumulating in leachates (Pool 1), interstitial water of a $1 \mathrm{~m}$ sand strip, and final drainage Pool 2. Data derived from amounts of material accumulated on the final day of experiment (Table 2) multiplied by the volumes of water in each of the 3 sections of the microcosm

\begin{tabular}{|lrrrrrr|}
\hline \multicolumn{1}{|c}{ Source } & Carbon & $\mathrm{NH}_{3}$ & $\mathrm{NO}_{2}$ & $\mathrm{NO}_{3}$ & Total N & $\mathrm{PO}_{4}$ \\
\hline Pool 1 & 4639.5 & 72.48 & 0.07 & 0.002 & 72.550 & 1.30 \\
Interstitial & 0.0 & 8.02 & 0.04 & 0.004 & 8.064 & 0.01 \\
Pool 2 & 233.1 & 77.07 & 0.01 & 0.000 & 77.080 & 0.46 \\
& & & & & & \\
\hline
\end{tabular}

export to the adjacent coastal waters. It is apparent that approximately $95 \%$ of the carbon ist used up during passage through the sand column (see also Koop et al., 1982). Although there es some evidence of utilisation of nitrogen in the sand, nitrogen accumulation in the leachate pool is similar to that draining from the sand column to the sea (Pool 2).

Nitrogen leaching to the sea is dominated by $\mathrm{NH}_{3}$. This is in agreement with the results of Raine and Patching (1980) and thus potentially significant as a source of nitrogen for nearshore primary producers (Lewin et al., 1975; McLachlan et al., 1981). In order to arrive at a mass balance for the remineralisation of carbon and nitrogen, however, it is necessary to express the residual components leaching to the sea in terms of the amounts contained in the material initially cast ashore.

\section{Mass Balance for a Sand Beach Microcosm}

It is now possible to calculate a mass balance for carbon and nitrogen during decomposition of the kelp debris and to estimate the quantitative significance of 
mineralisation products leaching to the sea. The results are summarised in Table 4 . Since the wet weight: dry weight ratio of Ecklonia maxima is $6.5: 1$ (Newell et al., 1980) and the carbon and nitrogen was found to be $32.08 \%$ and $1.87 \%$ of the dry weight respectively, the initial $26.35 \mathrm{~kg}$ wet kelp supplied to the microcosm corresponds to $1300.5 \mathrm{~g} \mathrm{C}$ and $75.8 \mathrm{~g} \mathrm{~N}$.

Koop et al. (1982) have estimated that $8.9 \%$ of the kelp carbon is directly removed by grazing invertebrates while $6.9 \%$ is returned as faeces. This yields a net loss of $26.0 \mathrm{~g} \mathrm{C}(=2 \%)$ from the microcosm by grazing. The residual dried kelp remaining at the end of the experiment amounted to $8 \%$ of the carbon initially supplied and together with the sum of the residual carbon in the water (Table 3) this gives $162.5 \mathrm{~g} \mathrm{C}$. The carbon available for microbial decomposition is thus $1300.5-(26.0+162.5)=1112.0 \mathrm{~g}$. The total bacterial biomass in the microcosm has been estimated to be $622.2 \mathrm{~g}$ dry weight (Koop et al., 1982) which yields a carbon equivalent of $311.1 \mathrm{~g}$ (Luria, 1960 ). The carbon conversion efficiency by the bacteria in the microcosm is thus $28.0 \%$, a value which accords well with that of $31 \%$ recorded for some bacteria by Fenchel and Blackburn (1979). It is also clear that carbon leaching from the microcosm to the sea (Pool 2) amounts only to some $0.2 \%$ of that originally supplied in the debris while that lost, presumably as $\mathrm{CO}_{2}$ to the atmosphere, is $100-(2+28.0+0.2)=69.8 \%$ (Fig. 2$)$.

In much the same way, the net exchange of nitrogen within the microcosm and the significance of drainage to the sea can be estimated from the difference between the amount supplied in the kelp and that incorporated into grazers plus bacteria and that remaining in the water of the microcosm (Table 3). In this case the nitrogen removed by grazing amounted to $6.7 \mathrm{~g}$ while the nitrogen equivalent of the faeces was $5.2 \mathrm{~g}$ yielding a net loss of $1.5 \mathrm{~g} \mathrm{~N}$ to grazers. The total

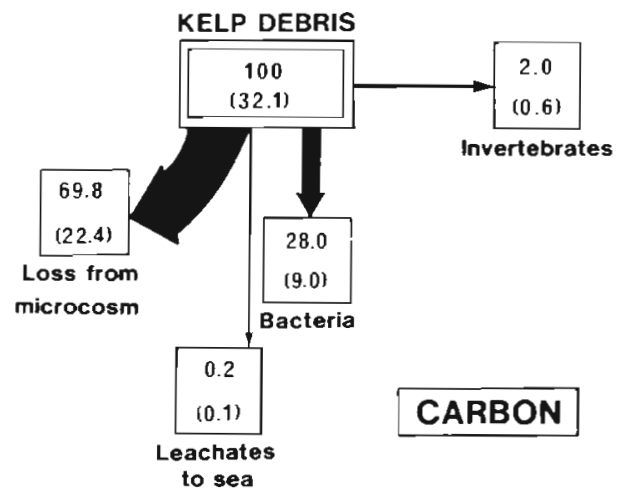

Fig. 2. Mass balance of carbon from decomposing kelp EckIonia maxima on the strandine. Figures expressed in g carbon, derived from an initial $100 \mathrm{~g}$ carbon in kelp; values in parentheses represent the weight $(\mathrm{g})$ of carbon derived from $100 \mathrm{~g}$ dry weight of kelp
Table 4. A carbon and nitrogen mass balance for the decomposition of kelp Ecklonia maxima on the strandline. Wet weight: dry weight and $C: N$ ratios of $6.5: 1$ and $17.2: 1$ respectively were used for kelp conversions. Removal by invertebrates and biomass of bacteria were calculated from Koop et al. (1982), residues from Table 3. Percentage loss from microcosm represents material not incorporated into biomass or returned to the sea and is probably lost to the atmosphere

\begin{tabular}{|lcc|}
\hline \multicolumn{1}{|c}{ Source } & $\begin{array}{c}\text { Carbon } \\
(\mathrm{g})\end{array}$ & $\begin{array}{c}\text { Nitrogen } \\
(\mathrm{g})\end{array}$ \\
\hline Total amount deposited & 1300.5 & 75.8 \\
Net removal by invertebrates & & \\
$\quad$ amount removed by grazing & 115.7 & 6.7 \\
amount returned as faeces & 89.7 & 5.2 \\
difference & 26.0 & 1.5 \\
\% incorporation & $2.0 \%$ & $2.0 \%$ \\
Residues in microcosm & 104.0 & 6.1 \\
dried kelp & 55.7 & 1.0 \\
dissolved matter in Pool 1 & 0.0 & 0.1 \\
dissolved matter in interstitial & 2.8 & 1.1 \\
dissolved matter in Pool 2 & 162.5 & 8.3 \\
Total residues & 1112.0 & 66.0 \\
Material available for microbial & & \\
decomposition & 311.1 & 62.2 \\
Biomass of bacteria & $28.0 \%$ & $94.2 \%$ \\
Bacterial conversion efficiency & $0.2 \%$ & $1.5 \%$ \\
Percent retumed directly to sea & $69.8 \%$ & $2.3 \%$ \\
Percent loss from microcosm & & \\
\hline
\end{tabular}

residual nitrogen in the microcosm at the end of the study was $8.3 \mathrm{~g}$ (Table 3 ) leaving $66.0 \mathrm{~g} \mathrm{~N}$ for microbial utilisation. The nitrogen equivalent of the bacterial biomass, using a $\mathrm{C}: \mathrm{N}$ ratio of $5: 1$ (Fenchel and Blackburn, 1979) is $62.2 \mathrm{~g}$. The nitrogen conversion efficiency of the bacteria in the microcosm was thus as high as $94.2 \%$. Although, as noted on p. 93, the concentrations of $\mathrm{NH}_{3}$ returned to the sea as leachates

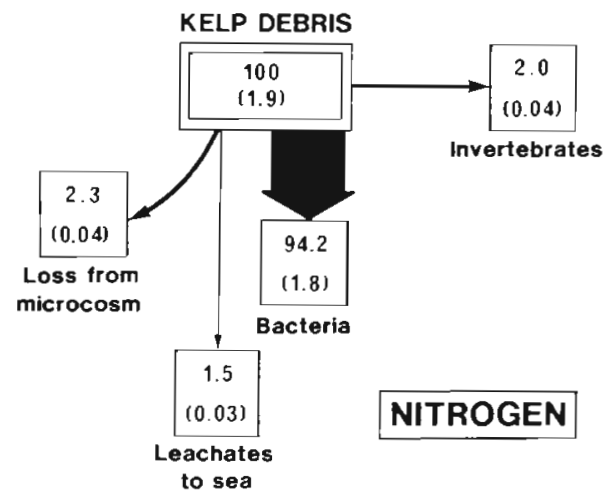

Fig. 3. Mass balance of nitrogen from decomposing kelp Ecklonia maxima on the strandline. Figures expressed in $\mathrm{g}$ nitrogen, derived from an initial $100 \mathrm{~g}$ nitrogen in kelp; values in parentheses represent the weight $(\mathrm{g})$ of nitrogen derived from $100 \mathrm{~g}$ dry weight of kelp 
were high, it is apparent that these comprise only $1.5 \%$ of the nitrogen supplied in the kelp debris. Nitrogen loss to the environment amounted to only 100 $-(1.5+94.2+2)=2.3 \%$ (Fig. 3).

The mass balance for the decomposition of kelp thus clearly shows that microbial incorporation of nitrogen from the kelp debris is as much as $94.2 \%$ efficient and is accompanied by mineralisation of approximately $70 \%$ of the carbon. Because there is no net accumulation in sandy beaches with successive cycles of decomposition, however, it is obvious that the material incorporated into bacteria is eventually returned to the environment.

\section{CONCLUSION}

Using the data cited above for the carbon and nitrogen exchange within an experimental sand beach microcosm, it is possible to estimate the annual fluxes on the strandline and the potential significance of ammonia regenerated from microbial activity in the intertidal zone for primary production in the adjacent coastal waters. Koop et al. (1982) have estimated that $206.01 \mathrm{~g}$ carbon $\mathrm{d}^{-1}$ are cast onto each metre of strandline from a kelp bed at Kommetjie, whose production is known. Since the $C: N$ ratio of kelp is $17.2: 1$, the nitrogen input to the beach is $12.0 \mathrm{~g} \mathrm{~N} \mathrm{~m}^{-1}$ of strandline $\mathrm{d}^{-1}$. From Table 4 we know that $0.2 \%$ of the carbon and $1.5 \%$ of the nitrogen is regenerated and returned to the sea by leaching. The carbon returned to the sea is thus $0.4 \mathrm{~g} \mathrm{~m}^{-1}$ of strandline $\mathrm{d}^{-1}$, while the nitrogen is $0.2 \mathrm{~g} \mathrm{~m}^{-1} \mathrm{~d}^{-1}$.

Newell et al. (1982) have summarised the primary production of Cape coast kelp beds and have reported that the combined production of kelp bed phytoplankton, understorey algae and kelp plus epiphytes amounts to $58,700 \mathrm{~kJ} \mathrm{~m} \mathrm{~m}^{-2} \mathrm{yr}^{-1}$. For a kelp bed of $1000 \mathrm{~m}$ width seawards, the carbon primary production would thus amount to $3710 \mathrm{~g} \mathrm{C}$ for a $1 \mathrm{~m}$ wide strip $\mathrm{d}^{-1}$. Equally, nitrogen production would amount to $215.7 \mathrm{~g}$ $\mathrm{N} \mathrm{d}^{-1}$ in the same $1 \mathrm{~m} \times 1000 \mathrm{~m}$ strip. Since, as shown above, nitrogen regeneration from the beach is $0.2 \mathrm{~g}$ $\mathrm{II}^{-1}$ of beach $\mathrm{d}^{-1}$, it follows that leaching could supply only $0.2: 215.2=0.09 \%$ of the nitrogen requirements of the adjacent kelp bed. Even if all the nitrogen incorporated into bacteria were ultimately returned to the sea, it is clear that this could meet only $11.7: 215.7$ $=5.4 \%$ of the nitrogen requirements of the adjacent kelp bed.

It is also possible to estimate the potential significance of microbial regeneration of ammonia to surf zone phytoplankton. Primary production by the kelp bed phytoplankton is estimated as $23,900 \mathrm{~kJ} \mathrm{~m}^{-2}$ of kelp bed $\mathrm{yr}^{-1}$ (Newell et al., 1982). McLachlan et al.
(1981) have defined a surf zone of $1 \mathrm{~m}$ width and depth $\times 200 \mathrm{~m}$ seawards as characteristic of exposed sandy beaches. The nitrogen requirements of such a zone would amount to $50 \mathrm{~g} \mathrm{~N} \mathrm{~d}^{-1}$ using a $\mathrm{C}: \mathrm{N}$ ratio of $6: 1$ for phytoplankton and the primary production figures cited above. Leachates from the shore could thus supply only $0.2: 50=0.4 \%$ of the estimated phytoplankton requirements even from a strandline where organic input is high. The contribution is probably even less on open exposed beaches where less debris is deposited on the strandline and where primary production by the surf zone diatoms is high (Lewin et al., 1975).

The sand beach ecosystem thus receives an organic input from the adjacent coastal zone and largely conserves the nitrogen in the debris cast up onto the strandline. While as much as $70 \%$ of the carbon is mineralised by the microbial community, combined losses of nitrogen amount only to $3.8 \%$ of the original amount supplied to the shore. Although there is no information to date on the further fate of the material immobilised by bacteria, it is clear that some of the nitrogen may leach back to the sea after the bacteria themselves have been mineralised. This would indicate that as much as $95 \%$ of the nitrogen cast up onto the strandline may ultimately be returned to the sea, though there may be further losses to the atmosphere at this step. However, even if a very large proportion of the nitrogen input returns to the nearshore water, this could still meet only a rather small fraction of the nitrogen requirements in that habitat. Primary production in the kelp bed community must therefore be dependent mainly on in situ regeneration of nutrients and on local upwelling. Although the high concentrations of ammonia regenerated from the decomposing kelp may have strictly localised significance in the immediate subtidal zone, the mass balance for the decomposition of macrophyte debris shows clearly that leachates from the strandline could meet only a small proportion of the nitrogen requirements of the primary producers in the adjacent nearshore ecosystem.

Acknowledgements. We are grateful to Ms. Colette Weimar of the Pollution Monitoring Unit, National Research Institute for Oceanology, and Mr. W. R. T. Hemsted of the Organic Chemistry Department, University of Cape Town for carrying out the analyses. The work was supported by funds from the South African National Committee for Oceanographic Research through the Benguela Ecology Programme at the University of Cape Town. R. C. Newell and M. I. Lucas are supported by funds from the Royal Society, London.

\section{LITERATURE CITED}

Armstrong, F. A. G., Sterns, C. R., Strickland, J. D. H. (1967). The measurement of upwelling and subsequent biological processes by means of the Technicon Autoanalyzer and associated equipment. Deep Sea Res. 14: 381-389 
Fenchel, T., Blackburn, T. H. (1979). Bacteria and mineral cycling, Academic Press, London

Koop, K., Newell, R. C., Lucas, M. I. (1982). Biodegradation and carbon flow based on kelp (Ecklonia maxima) debris in a sandy beach microcosm. Mar. Ecol. Prog. Ser. $7_{i}$ 315-326

Lewin, J., Hruby, T., Mackas, D. (1975). Blooms of surf zone diatoms along the coast of the Olympic Peninsula, Washington. V. Environmental conditions associated with the blooms (1971 and 1972). Estuar. coast. mar. Sci. 3: 229-241

Luria, S. E. (1960). The bacterial protoplasm: Composition and organisation. In: Gunsalus, I. C., Stanier, R. Y. (eds.) The bacteria, Vol, 1. Academic Press, New York, pp. 1-34

McLachlan, A., Erasmus, T., Dye, A. H., Wooldridge, T., Horst, G. van der, Rossouw, G., Labiak, T. A., Mc Gwynne,
L. (1981). Sand beach energetics: an ecosystems approach towards a high energy interface. Estuar coast. Shelf Sci. 13: $11-25$

Newell, R. C., Field, J. G., Griffiths, C. L. (1982). Energy balance and the significance of micro-organisms in a kelp bed community. Mar. Ecol. Prog. Ser. 8: 103-113

Newell, R. C., Lucas, M. I., Velimirov, B., Seiderer, L. J (1980). Quantitative significance of dissolved organic losses following fragmentation of kelp (Ecklonia maxima and Laminaria pallida). Mar. Ecol. Prog. Ser. 2: 45-59

Raine, R. C. T., Patching, J. W. (1980). Aspects of carbon and nitrogen cycling in a shallow marine environment. J. exp. mar. Biol. Ecol. 47: 127-139

Strickland, J. D. H., Parsons, T. R. (1972). A practical handbook of seawater analysis, 2nd ed. Bull. Fish. Res. Bd Can. 167

This paper was presented by Professor J. G. Field; it was accepted for printing in March 28, 1982 